\title{
Islamic Menstrual Holistic Care Education Class for Young Women during the Covid-19 Pandemic
}

\author{
Aida Ratna Wijayantia) Inna Sholicha Fitriani, and Sholihatul Maghfiroh \\ Universitas Muhammadiyah Ponorogo, Ponorogo, Indonesia \\ a) Corresponding author: aidaratna.Bd@gmail.com)
}

\begin{abstract}
Physical and psychological changes that occur in adolescent girls, especially at the beginning of puberty can affect anxiety which leads to the risk of decreased body immunity. The purpose of this service is that young women can prepare for or undergo puberty and puberty safely, comfortably and can reduce the risk of anemia and decreased endurance, especially during the pandemic Covid-19. The location of the service is at the LKSA Orphanage of Nurus Syamsi Muhammadiyah, Bungkal District, Ponorogo Regency, East Java. Service activities in the form of educational classes with conventional methods, discussions. In the education class, 3 (three) different materials were given, namely 1) Puberty and Akil Baligh, 2) Myths About Menstruation, 3) Thaharoh and Practices During Menstruation. In this educational class, young women are also given blood-boosting multivitamins to prevent anemia during menstruation. After this service activity is carried out, it is hoped that there will be awareness in maintaining cleanliness and health during puberty, especially to reduce the risk of anemia in young women in orphanages during the pandemic Covid-19.
\end{abstract}

Keywords: Puberty, baligh, menstruation, adolescence, girls

\section{INTRODUCTION}

At the beginning of adolescence, not all of them are ready to face physical and psychological changes. Most of the youth need assistance and education regarding the changes that occur. Not infrequently they experience anxiety due to a lack of knowledge. Adolescents are between 10 and 19 years of age and are divided intoyouth15-24 years of(WHO, 2015). In Indonesia, adolescents are people aged 10-19 years (Minister of Health, 2014). Adolescence is a period of transition from childhood to adulthood. In this transitional period, there are physical and psychological changes towards the maturity of the reproductive organs (WHO, 2015). In young women, it is marked by the occurrence of the first menstruation and changes in body shape. Menstruation is a sign of the maturity of the female reproductive organs that causes blood to flow from the uterus to the vagina. Menstruation normally occurs in every woman, the menstrual cycle ranges from 22-35 days, 2-7 days long (Kusmiran, 2014). During menstruation, the body can lack iron which can lead to anemia.

There have been many studies and services related to reproductive health that have been carried out on young women both at school and in orphanages. The results of previous studies indicate that there is still a lack of knowledge and attitudes related to hygiene during menstruation (Aaktifah \& Fortune, 2013). The incidence of anemia and dysmenorrhea in adolescent girls in orphanages (Hamdiyah, 2020). The need for assistance or education in orphanages will make the self-concept better and the higher the ability shown by adolescents to adjust (Hidayati, 2016).

The Child Welfare Institution (LKSA) Nurus Syamsi Muhammadiyah Orphanage is located at JI. Puntodewo No. 11 Dukuh Kudo, Bungkal Village, Ponorogo Regency, is one of the orphanages in Ponorogo Regency. This orphanage has 30 young women with ages ranging from 8-24 years. An initial survey conducted at the LKSA Nurus Syamsi Bungkal Orphanage found that there was still a lack of knowledge about menstruation and the existence of several myths that still existed among young women related to menstruation. Limited access to 
reproductive health education directly with health workers during a pandemic can have an impact on health and anxiety when dealing with menstruation. Therefore, this service in the form of educational classes for young women at the LKSA Nurus Syamsi Orphanage aims to help increase knowledge related to reproductive health, especially menstruation, myths about menstruation and worship or taharah for young women. So we hope that there will be an increase in knowledge and health so that it can prevent anemia at the LKSA Nurus Syamsi Orphanage Muhammadiyah Bungkal, Ponorogo Regency.

\section{MATERIALS AND METHODS}

An educational class on Islamic holistic care for menstruation as prevention of anemia in adolescent girls during the Covid-19 pandemic was held at the LKSA Nurus Syamsi Orphanage, Muhammadiyah Bungkal, Ponorogo Regency. The location of the service is at the Putri Orphanage JI. Puntodewo No. 11 Hamlet Kudo, Bungkal Village, Ponorogo Regency which is $17.1 \mathrm{~km}$ from Muhammadiyah University of Ponorogo. There are 25 Young Women with an age range of 8-24 years. Service activities were carried out on July 24, 2021, using conventional methods and discussions held virtually through the application zoom meeting due to the Implementation of Community Activity Restrictions (PPKM) during the Covid-19 Pandemic Period.

The service team carried out several activities, namely firstly distributing questionnaires that had been deposited in the orphanage to determine the knowledge of young women about the material to be presented. Second, three materials related to menstruation are given, namely 1) Puberty and Akil Baligh, 2) Myths About Menstruation, 3) Thaharoh and practice during menstruation through virtual using zoom meeting. The third is the evaluation of the success of the educational class through a questionnaire. The imposition of restrictions on community activities is the reason for doing virtual service. The caretaker of the orphanage conducts monitoring at the location (Nurus Syamsi Muhammadiyah Orphanage), assisting the implementation of virtual education classes. This service does not only provide education but also provides personal protective equipment (PPE) and multivitamin needs for young women in orphanages in preventing anemia. provided Rewards are for young women who are active during the educational class.

\section{RESULTS}

There have been community service activities in the form of virtual education classes through zoom meetings at the Nurus Syamsi Muhammadiyah Bungkal Orphanage, Ponorogo Regency, attended by 29 participants with an age range of 8-24 years.

The results of the initial questionnaire distributed before the education class obtained an average of $32 \%$ correct answers and $68 \%$ incorrect answers. The implementation of the Educational Class lasts for \pm 3 hours virtually. During the presentation of the material, and interaction was carried out by giving several questions or discussions. It was seen that there was enthusiasm from young women with many questions that entered the feature chat and questions directly from participants. At the end of the service, the questionnaire was given back to be filled out. The results of the questionnaire showed that the average correct answer was $91 \%$ and the wrong answer was $9 \%$.

\section{DISCUSSION}

The meeting of the service team with the head of the Nurus Syamsi Muhammadiyah Orphanage gave an overview of the conditions that occurred in the orphanage. One of them is the existence of myths related to menstruation which are still often discussed and believed by young women, the lack of knowledge regarding personal hygiene during menstruation, and taharah and practices that can be done during menstruation. According to the head of the orphanage, education classes related to Islamic holistic care for menstruation have never been conducted at the orphanage. 
The initial questionnaire given before the educational class activity took place gave an illustration of the low knowledge of young women related to puberty, myths, and taharah. During the implementation of the education class, there was an enthusiasm of young women to ask and answer questions from the service team, but there were obstacles in the virtual education class, namely an unstable internet network, a room that was not comfortable because the hall that was usually used could not be used. The evaluation of the education class with a questionnaire was carried out after the service team had finished presenting the material and asking questions. It was hoped that the service team would be able to provide the material well so that the young women at the Nurus Syamsi Orphanage Muhammadiyah Bungkal could understand it.

The pre-class and post-education questionnaires were the same. The team analyzed the post-education class questionnaire, and it was found that there was an increase in knowledge marked by an increase in the average correct answer. Many reproductive health counseling activities for young women have been carried out in orphanages. The service activities for reproductive health counseling for adolescent girls in the city of Padang have a positive impact, namely, the ability to think critically can provide examples of reproductive health in the environment and can address the myths circulating regarding menstruation (Yulizawati, 2018). Counseling activities through online classes can increase the percentage to $100 \%$ regarding knowledge of menstruation, hygiene, and physical changes that occur (Rahmayanti, 2020).

Due to the limitations of the team and the density of the orphanage's activities, the educational class which was planned to be held 3 times was only conducted once so that to make it easier to recall the material that had been presented, the service team made an animated video recording related to puberty and puberty for young girls.

\section{CONCLUSIONS AND RECOMMENDATIONS}

The Islamic menstrual holistic care education class resulted in an increase in knowledge by the expected goals in service. The existence of unstable network constraints during the education class did not hinder the service team and also the team at the orphanage in pursuing the success of the education class. It is still necessary to take concrete actions at the Orphanage to see firsthand how Menstrual Hygiene Management (MKM), Thaharah practices and practices during menstruation, as well as other possibilities of reproductive health problems and their direct impact on adolescent girls. No less important is the need for a thorough health examination, especially to prevent anemia.

\section{ACKNOWLEDGMENTS}

The Community Service Team of the Faculty of the Health Sciences University of Muhammadiyah Ponorogo would like to thank the LKSA Nurus Syamsi Orphanage of Muhammadiyah Bungkal, Ponorogo Regency for being willing to become partners in community service activities and LPPM Muhammadiyah University of Ponorogo who have provided financial support for the implementation of community service in 2021.

\section{REFERENCES}

Aktifah, N., \& Rejeki, H. (2013). Pengetahuan dan Sikap Remaja Panti Asuhan Yatim (PAY) Aisiyah Pekajangan tentang Vulva Hygiene Pada Saat Menstruasi. Jurnal IImiah Kesehatan, 5(2), 109.

Hamdiyah. 2020. "Hubungan Anemia Terhadap Dysmenorrhea (Nyeri Haid) Pada Remaja Putri Di Panti Asuhan Sejahtera Aisyiyah Sidrap". Madu Jurnal Kesehatan. Volume 9 (1) :816

Kusmiran Eny. (2014). Kesehatan Reproduksi Remaja dan Wanita. Jakarta: Salemba Medika. Menteri Kesehatan RI. Upaya Kesehatan Anak. , Pub. L. No. PERATURAN MENTERI KESEHATAN REPUBLIK INDONESIA NOMOR 25 TAHUN 2014 (2014).

Rahmayanti, R., Wahyuni, F., Yazia, V., Handayani, D., \& Hasni, H. (2020). Pentingnya Menjaga 
Kesehatan Di Masa Pandemi Covid-19 Pada Remaja Di Panti Aisyiyah Lubuk Minturun. Abdimas Galuh, 2(2), 158. https://doi.org/10.25157/ag.v2i2.4057

WHO. (2015). Adolescent Health in South-East Asean Region. Retrieved from https://www.who.int/southeastasia/health-topics/adolescent-health. [24/7/2021]

Yulizawati, Dilla Fitri, Siti Hanisa Khaira, J. W. (2018). LAPORAN PENGABDIAN MASYARAKAT Penyuluhan Kesehatan Reproduksi pada Remaja Putri di Panti Asuhan Aisyiyah Nanggalo Padang. 
APPENDIX

Table 1. Pre-educational pre-class questionnaire

\begin{tabular}{llcc}
\hline & \multicolumn{1}{c}{ Material } & \multicolumn{2}{c}{$\begin{array}{c}\text { Percentage (\%) } \\
\text { Answers }\end{array}$} \\
\cline { 3 - 4 } $\mathbf{N}$ & & True & False \\
\hline & & 24 & 76 \\
2 & Puberty and Akil Baligh & 17 & 83 \\
3 & Myths About Menstruation & 55 & 45 \\
\hline & Thaharah and Practice During Menstruation & 32 & 68 \\
\hline
\end{tabular}

Table 2. Post-educational questionnaire

\begin{tabular}{|c|c|c|c|}
\hline $\mathbf{N}$ & \multirow[t]{2}{*}{ Material } & \multicolumn{2}{|c|}{$\begin{array}{c}\text { Percentage (\%) } \\
\text { Answers }\end{array}$} \\
\hline $\mathbf{0}$ & & True & False \\
\hline 1 & Puberty and Akil Baligh & 83 & 17 \\
\hline 2 & Myths About Menstruation & 100 & 0 \\
\hline 3 & Thaharah and Practices During Menstruation & 90 & 10 \\
\hline & Average & 91 & 9 \\
\hline
\end{tabular}
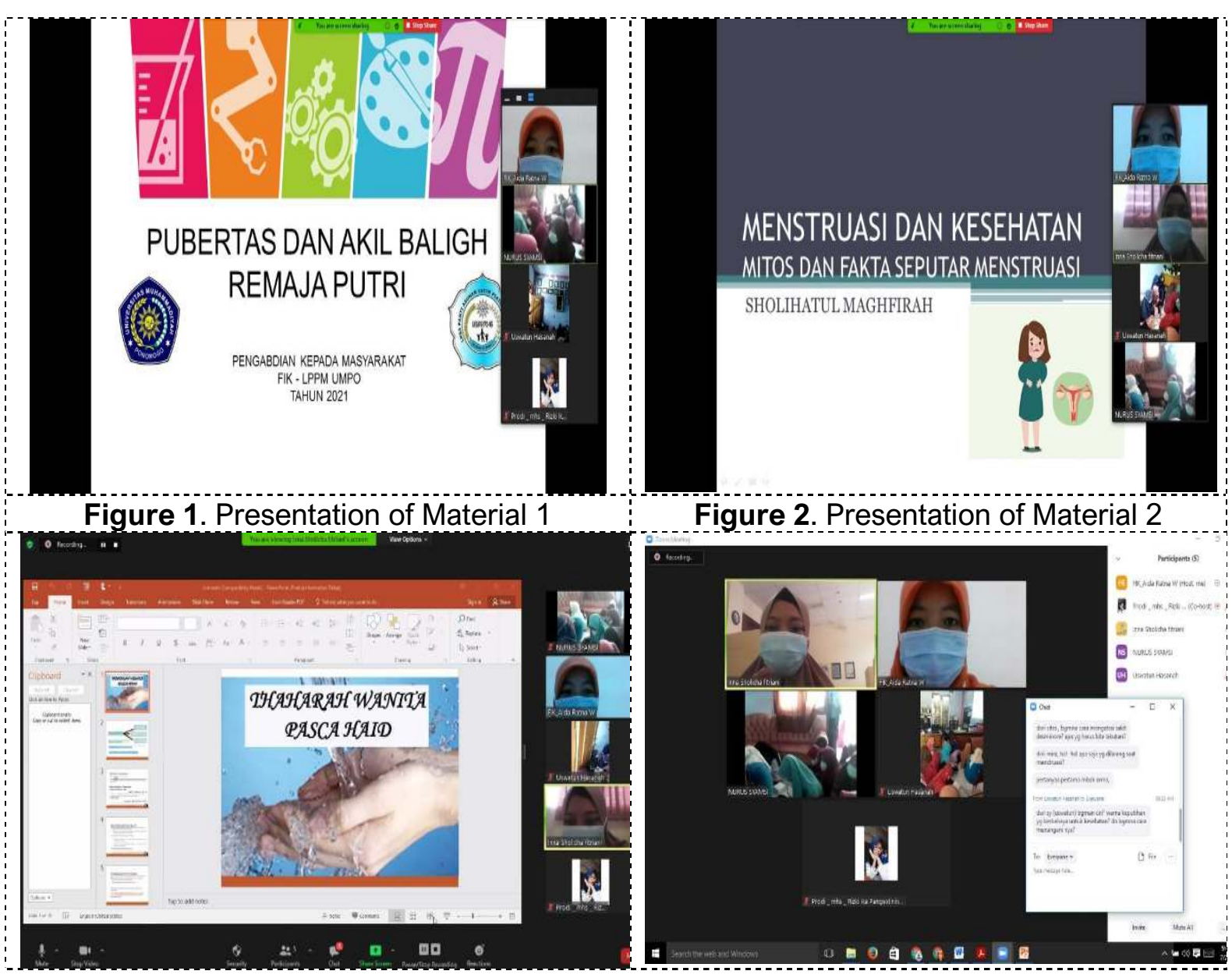

Figure 2. Presentation of Material 2

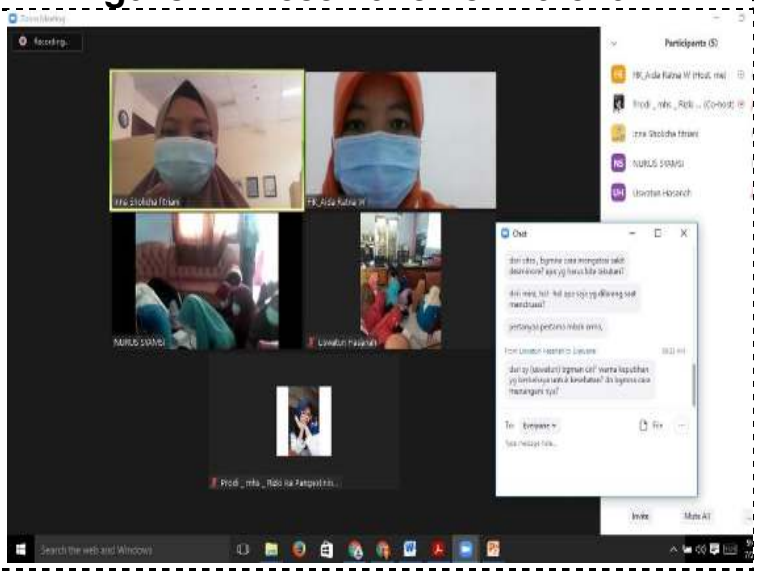


Figure 3. Presentation of Material 3

Figure 4. Discussion and Question and Answer Activities in Educational Class 